\title{
Mardin ili Kızıltepe ilçesi makarnalık buğday (Triticum durum desf.) yetiştirilen tarım alanlarının verimlilik durumlarının toprak ve tane mineral analizleriyle belirlenmesi
}

Determination of productivity status of agricultural lands growing durum wheat (Triticum durum desf.) in Kızıltepe district of Mardin province by soil and grain mineral analysis

\author{
Uğur BiLGE ${ }^{1}$ iD, K. Mesut ÇiMRiN ${ }^{2}$ iD, Abdullah EREN ${ }^{3}$ iD \\ ${ }^{1}$ GAP International Agricultural Research and Training Center, Diyarbakır, Turkey. \\ ${ }^{2}$ Hatay Mustafa Kemal University, Faculty of Agriculture, Department of Soil Science and Plant Nutrition, Antakya-Hatay, Turkey. \\ ${ }^{3}$ Mardin Artuklu University, Vocational Higher School of Kızıltepe, Department of Organic Agriculture, Mardin, Turkey.
}

MAKALE BILGISI / ARTICLE INFO

\section{Makale tarihçesi / Article history:}

DOI: $\underline{10.37908 / m k u t b d .893138}$

Geliş tarihi /Received:08.03.2021

Kabul tarihi/Accepted:12.04.2021

\section{Keywords:}

Durum (Triticum durum Desf.) wheat, soil fertility, plant nutrient elements, heavy metals, grain analysis.

\footnotetext{
Corresponding author: K. Mesut ÇiMRIN

$\bowtie$ : mcimrin@hotmail.com
}

\section{Ö ZET / A B S TR A C T}

Atıf / Citation: Çimrin KM, Yalçın M, Keleş N (2021) Determination of productivity status of agricultural lands growing durum wheat (Triticum durum desf.) in KızIltepe district of Mardin province by soil and grain mineral analysis. MKU. Tar. Bil. Derg. 26(2) : 306-315. DOI: $10.37908 /$ mkutbd.893138

\section{Giriş}

Buğday üretimi içerisinde makarnalık buğday (Triticum durum Desf.) üretimi dünya ve ülkemizde önemli bir yere sahiptir. Buğday günümüzde ılıman iklimlerden Avrupa'nın kuzeyine, güney Amerika'dan tropik ülkelere kadar geniş bir coğrafyada yetiştirilmektedir (Özberk ve ark., 2016). Günümüz toplumlarında değişen beslenme 
alışkanlıklarına rağmen tahıl ve tahıl ürünleri dünya nüfusunun beslenmesinde önemli bir yer tutmaktadır. Tam buğday unu, besinsel lif, mineral maddeler, B kompleks vitaminler, antioksidanlar (fitik asit, glutatiyon ve tokoferol vb.) ve elzem aminoasitler bakımından çok ucuz bir kaynaktır. Aynı zamanda, iyi azot $(\mathrm{N})$ dengesine sahip protein ve yüksek nişasta içeriği ile de uygun ve çok ucuz bir enerji kaynağıdır (Demir, 2018). Buğday insan beslenmesi için gerekli olan kalori ve proteinin önemli bir kısmını karşılamakta olup dünya nüfusunun \%35'ini oluşturan yaklaşık 40 ülkenin ana besin kaynağıdır. Insanların değişen tüketim alışkanlıkları ve gelişen teknolojiye bağlı olarak, buğday ürünleri çeşitlenmekte ve tüketici isteklerine bağlı olarak değişmektedir. Buğday yaygın olarak ekmek, makarna, irmik, bisküvi ve bulgur şeklinde tüketilmektedir (Kendal ve ark., 2012).

Ülkemizde makarnalık buğday ihtiyacı büyük oranda Güneydoğu Anadolu Bölgesinden karşılanırken, Orta Anadolu ve Trakya-Marmara Bölgeleri de makarnalık buğday üretimi için uygun ekolojiye sahip bölgelerdendir (Ayçiçek ve ark., 1997). Güneydoğu Anadolu Bölgesi buğdayın gen merkezi konumunda olup, özellikle yerel makarnalık çeşitleri bakımından önemli bir bölgedir (Çı̆̆ ve Karaman 2019). Buğdayın yüksek adaptasyona sahip olması tüm dünyada olduğu gibi ülkemizde de ekim ve üretim alanı bakımından en geniş tahıl ürünüdür (Dönmez ve Coşkan, 2020). Türkiye'nin 37.8 milyon hektar toplam tarım alanının 15.4 milyon hektarını tahıllar ve diğer bitkisel ürünler oluşturmaktadır. 2019 yılı buğday ekilişi 68.5 milyon dekar, toplam üretimi 19 milyon tondur. 57.5 milyon dekar alanda 15.85 milyon ton ekmeklik buğday, 11 milyon dekar alanda da 3.15 milyon ton makarnalık buğday üretilmiştir (Anonim, 2019a).

Dünyada ya da ülkemizde bütün besin maddelerince dengeli tarım toprağı bulmak pek mümkün değildir. Bilindiği gibi bitkilerin normal gelişmelerini tamamlayabilmeleri için intiyaç duydukları mutlak bitki besin maddelerinin toprakta yeterli ve dengeli miktarda bulunması gerekmektedir. Bitkilerin ihtiyaç duydukları besin maddelerinin yetersiz olması durumunda, bitkide gelişme geriliği ile beraber verim ve kalitenin azalmasına neden olabilmektedir (Turan ve ark., 2010; Ayyıldız ve Eren 2020). Diğer yandan sorun sadece bitki besin maddelerinin eksikliği veya yeterli olması değil, bazı bitki besin maddelerinin fazlalığı, yüksek ya da düşük $\mathrm{pH}$, toprağın organik madde, kil miktarı, kireç içeriği ve nem gibi birçok etken tarafından besin elementlerinin alımını zorlaştırmaktadır (Keleş-Uzel ve Çimrin, 2020). Bilinçsiz ve gereğinden fazla gübre kullanımı toprakta olumsuz sonuçlara neden olmaktadır, bitki gelişimine olumsuz etkileri yanında, özellikle yeraltı ve yerüstü su kaynaklarının kirlenmesine neden olabilmektedir (Parlak ve ark. 2008; Eren, 2019). Bu nedenle farklı yöre ve bitkilerin toprak ve bitki örnekleri ile zaman zaman beslenme durumlarının belirlenmesi, yöredeki bitki çeşitliliği ve bu bitkilere nasıl bir gübreleme yapılacağının cevabı olmaktadır. Bu nedenle farklı yöre ve bitkiler için birçok araştırıcı tarafından benzer çalışmalar yürütülmüştür (Çimrin ve Boysan, 2006; Karaduman ve Çimrin, 2016; Çimrin, 2018; Bozgeyik ve Çimrin, 2020). Türkiye'de ekilen buğday alanı 2017/18 üretim sezonu itibariyle 76.7 milyon da olup, ekilen bu alanının \% 32'sini oluşturan ilk 10 il sırasıyla; Konya, Ankara, Diyarbakır, Yozgat, Urfa, Sivas, Çorum, Tekirdağ, Mardin ve Eskişehir'dir (TÜiK, 2021). Buğday tarımı üretim miktarları farklı olmakla birlikte Türkiye'nin her bölgesinde yapılmaktadır. Bundan dolayı buğday tarımı tarla ürünleri içinde en fazla üretimi yapılan üründür. Ülkemiz buğday üretim ve ekiliş alanının büyük bir bölümü iç Anadolu ile birlikte Güney doğu Anadolu bölgesinde gerçekleşmektedir. 2020 yılı için yapılan ilk değerlendirmelere göre makarnalık buğday ekiliş alanlarında Güneydoğu Anadolu bölgesinde artma olduğu BÜGEM (2021) tarafından belirtilmiştir. Mardin ili, Güneydoğu Anadolu Bölgesinde yüksek tarımsal potansiyele sahip olup, Mardin ovasında yetiştirilen tahıl ürünlerinin verim değerlerinin yüksek oluşu ve çok kolay işlenebilen arazilere sahip olması nedeniyle ülkemiz için önemli bir yere sahiptir (Eren, 2019).

Bu çalışma, Güneydoğu Anadolu Bölgesinde yer alan Mardin iline bağlı Kızıltepe illçesinde sulama olanağı bulunan bazı köy arazilerinde, makarnalık buğday yetiştiriciliği yapılan alanların mevcut beslenme sorunları ve toprak yapısının ortaya konulması, buğday tanelerinde ve toprak analiz verilerine dayalı olarak tarlaların gübreleme programlarının oluşturulmasına katkı sağlanması amaçlanmıştır.

\section{MATERYAL ve YÖNTEM}

Kızıltepe, Mardin ilinin batısında yer alan en büyük ilçesidir. İlçenin önemli bir kısmı ova olup, büyük bir kısmı düz alanlardan oluşmaktadır. Toplam alanın yaklaşık $1400 \mathrm{~km}^{2}$ olduğu ilçede, step ikliminin hakim olduğu, yazları kurak ve sıcak, kışları ise yer yer kar yağışlı ve soğuk bir iklime sahiptir. Mardin Ovasında yağışların, kışın; \% 49'u, ilkbaharda; \% 37'si, yazın; \% 0.9'u ve sonbaharda; \% 13'ü düşmektedir (Bahçeci ve Ayde, 2008; Sönmez, 2012; Eren 2019). Çalışma, Mardin ilinin Kızıltepe ilçesindeki 50 dönüm ve daha büyük tarlalarda, makarnalık buğday yetiştiriciliği yapılan 10 farklı köyden üçer farklı noktadan (Aktepe, Altıntoprak, Çağıl, Çamlıca, Çamlıdere, Ekinlik, İnandı, Sandıkı, Tozan ve Yaşar köy), 
0-30 cm derinlikten, toplam 30 adet toprak Jackson (1962) tarafından belirtilen esaslara göre alınmıştır (Şekil 1; Çizelge 1). Tarlaların üç farklı bölgesinden alınan buğday örnekleri saplarından ayrılarak tane örnekleri analiz yapılmak üzere saklanmıştır.

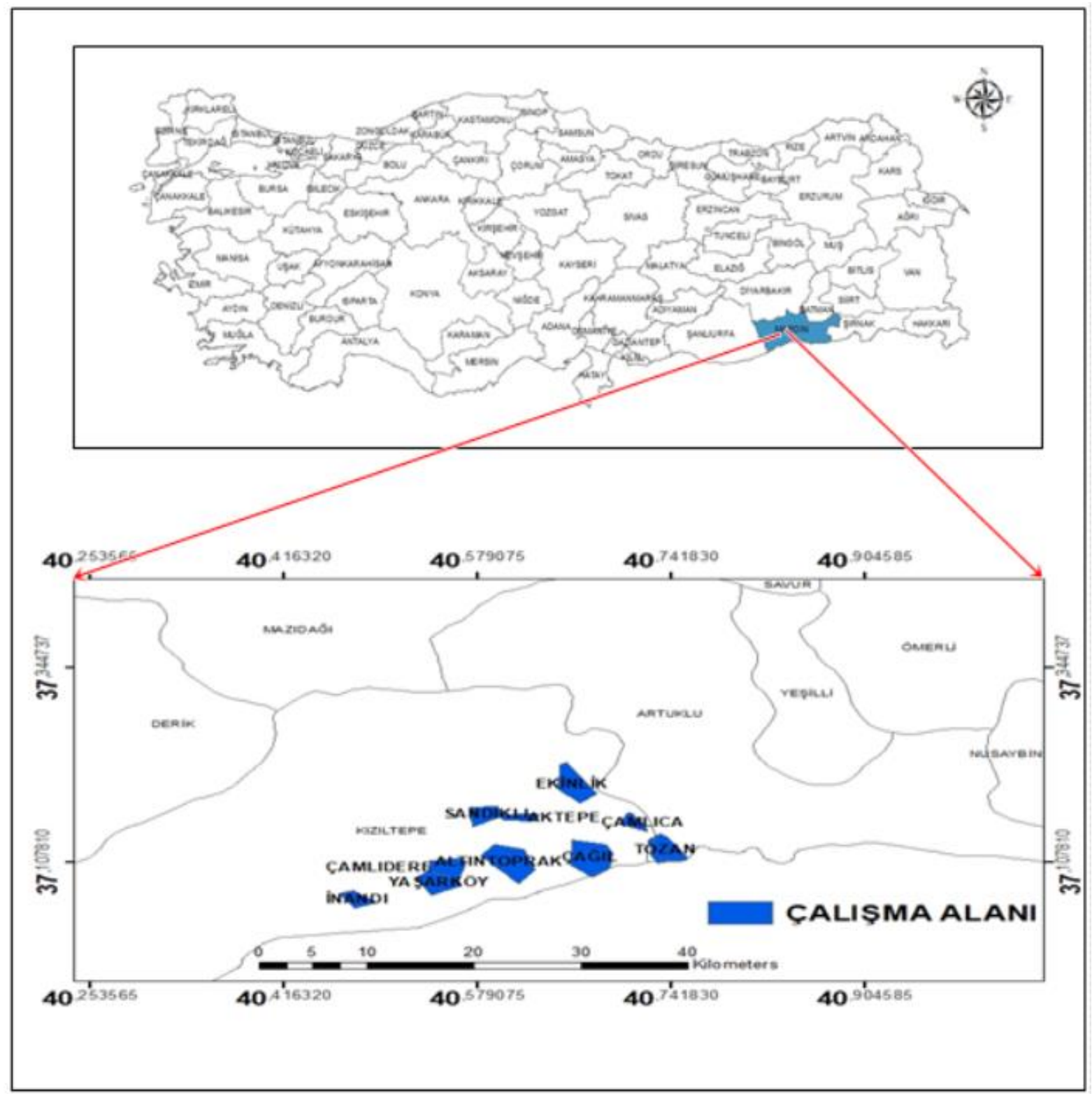

Şekil 1. Çalışma alanı konum haritası

Figure 1. Workspace location map

Toprak örneklerinde, $\mathrm{pH}$ saturasyon çamurunda Jackson (1962)'a, kireç kalsimetrik olarak Scheibler kalsimetresinde (Loeppert ve Suarez, 1996), toplam tuz ve bünye Richards, (1954)'e göre organik madde WalkleyBlack metoduna göre (Ülgen ve Ateşalp, 1972) belirlenmiştir. Alınan toprak örneklerinde yarayışlı $P$ sodyum bikarbonat ( $\mathrm{pH}=8.5$ ) yöntemiyle (Olsen ve ark., 1954), alınabilir potasyum Pratt (1965)'ın bildirildiği gibi 1.0 N nötr amonyum asetat ile ekstrakte edilerek alev fotometresinde, yarayışı $\mathrm{Zn}, \mathrm{Fe}, \mathrm{Mn}, \mathrm{Cu}$, Ni ve Cd DTPA ile çalkalanarak Lindsay ve Norvell (1978)'e göre ICP-OES cihazında belirlenmiştir (Plank,1992; Isaac ve ark., 1998). Buğday tanesinde Kjeldahl yöntemi ile belirlenen azotun 6.25 katsayı ile çarpımı ile \% protein belirlenmiştir (Bremner, 1965). Buğday tanesindeki P, K, Zn, Fe, Mn, $\mathrm{Cu}, \mathrm{Ni}$ ve $\mathrm{Cd}$ içerikleri örneklerin yaş yakma yöntemi ile elde edilen çözeltide (Isaac ve Kerber, 1971) ICP-OES cihazında belirlenmiştir (Plank,1992; Isaac ve ark., 1998). Elde edilen veriler korelasyon analizleri SPSS 22.0 paket proğramı ile yapılarak Düzgüneş ve ark. (1987)'a göre yorumlanmıştır. 
Çizelge 1. Toprak ve bitki örneklerinin alındığı köyler ve noktaların GPS koordinatları

Table 1.GPS coordinates of villages and points where soil and plant samples were taken

\begin{tabular}{lll}
\hline Köyler & \multicolumn{2}{c}{ Koordinat (UTM, m) } \\
\hline Aktepe-1 & 37.1560 & 40.6218 \\
Aktepe-2 & 37.1579 & 40.6182 \\
Aktepe-3 & 37.1549 & 40.6160 \\
\hline Altıntoprak-1 & 37.1099 & 40.5961 \\
Altıntoprak-2 & 37.1087 & 40.5930 \\
Altıntoprak-3 & 37.1071 & 40.5906 \\
\hline Çağıl-1 & 37.1183 & 40.6693 \\
Çağıl-2 & 37.1130 & 40.6650 \\
Çağıl-3 & 37.1160 & 40.6632 \\
\hline Çamlıca-1 & 37.1713 & 40.7041 \\
Çamlıca-2 & 37.1713 & 40.7069 \\
Çamlıca-3 & 37.1714 & 40.6997 \\
\hline Çamlıdere-1 & 37.0984 & 40.5445 \\
Çamlıdere-2 & 37.0973 & 40.5446 \\
Çamlıdere-3 & 37.1012 & 40.5451 \\
\hline Ekinlik-1 & 37.1966 & 40.6638 \\
Ekinlik-2 & 37.1995 & 40.6612 \\
Ekinlik-3 & 37.1931 & 40.6656 \\
\hline Inandı-1 & 37.0679 & 40.5066 \\
Inandı-2 & 37.0666 & 40.5087 \\
Inandı-3 & 37.0652 & 40.5056 \\
\hline Sandıklı-1 & 37.1628 & 40.5851 \\
Sandıklı-2 & 37.1586 & 40.5832 \\
Sandıklı-3 & 37.1571 & 40.5885 \\
\hline Tozan-1 & 37.1237 & 40.7353 \\
Tozan-2 & 37.1250 & 40.5500 \\
Tozan-3 & 37.1229 & 37.0838 \\
\hline Yaşarköy-1 & 37.0829 & \\
Yaşarköy-2 & 37.0823 & \\
Yaşarköy-3 & & \\
\hline & & \\
& 37.0836 & \\
\hline
\end{tabular}

\section{BULGULAR ve TARTIŞMA}

\section{Toprakların pH, kireç, tuz, organik madde, besin ve ağır metal içerikleri}

Çalışma alanından alınan toprakların bazı fiziksel ve kimyasal analiz sonuçları Çizelge 2.'de verilmiştir. Çizelge 2'nin incelenmesinden anlaşılacağı gibi, çalışma alanı topraklarının tümü Killi-Tın bünyeli, tuzsuz ve çok kireçli olarak belirlenmiştir. Toprakların en düşük pH içeriği 7.17 iken, en yüksek pH içeriği 7.81, ortalama pH 7.41 olarak belirlenmiştir. Bu topraklar Kellogg; (1952)'un sınır değerlerine göre sınıflandırıldığında pH'larının \% 76.67'si hafif alkalin (7.4-7.8) ve \% 23.33'ünün nötr (6.6-7.3) olduğu belirlenmiştir. Toprakların organik madde içerikleri \% 1.32-2.37 arasında değişim göstermiş olup Eyüpoğlu (1998)'nun bildirmiş olduğu sınır (\% 1.00-2.00) değerlerine göre örneklerin \%90'। "az" ve \% 10'u ise (\% 2.00-3.00) "orta" düzeyde olduğu belirlenmiştir. Eren
(2019) Kızıltepe ilçesinin bazı köylerinde yapmış olduğu çalışmada organik madde miktarları bakımından toprakların yaklaşık \% 67.4'ü "az", \% 32.6'sı ise "orta" seviyede olduğunu bildirmiştir.

Toprak örneklerinin yarayışı P içerikleri 8.25-24.9 mg kg

1 arasında değişim göstermiş, örnekleme yapılan Kızıltepe ilçesi toprakları FAO (1990)'nun bildirdiği sınır değerlerine göre "yeterli" (8.00-25.0 mg kg-1) düzeyde bulunmuştur. $\mathrm{Bu}$ durum, toprakların yüksek kireç içermesi ve buna bağlı olarak fosfor fiksasyon kapasitesinin yüksek olmasına rağmen yeterince ve hatta fazla fosforlu gübrelemenin yapıldığını düşündürmektedir. Toprakların potasyum (K) içerikleri 591-1120 mg kg ${ }^{-1}$ arasında değişim göstermiş ve Sumner ve Miller (1996)'in verdiği sınır değerlerine göre, "yüksek" (370-1000 $\mathrm{mg} \mathrm{kg}^{-1}$ ) ve "çok yüksek" (>1000 mg $\left.\mathrm{kg}^{-1}\right)$ düzeyde $\mathrm{K}$ içerikleri olduğu belirlenmiştir.

Makarnalık buğday ekimi yapılan toprakların çinko (Zn) içerikleri 0.51-1.26 mg kg-1 arasında değişim göstermiş olup, Sillanpää (1990)'nın belirlemiş olduğu sınır değerlerine göre sınıflandırıldığında \% 73.33'ü "çok az" (0.2-0.7 $\mathrm{mg} \mathrm{kg}^{-1}$ ) ve \% 26.67'si "az" (0.7-2.4 mg kg-1) düzeyde olduğu ve toprakların bu sonuçlara göre tümünün Zn noksanlığı gösterdiği belirlenmiştir. Toprakların demir (Fe) içeriği bakımından, 15.2-37.8 mg $\mathrm{kg}^{-1}$ arasında değişerek ortalama $22.6 \mathrm{mg} \mathrm{kg}^{-1}$ olup, Viets ve Lindsay (1973)'in bildirmiş olduğu sınır değerlerine göre ( $>4.5 \mathrm{mg} \mathrm{kg}^{-1}$ ) fazla miktarda olduğu belirlenmiştir. $\mathrm{Bu}$ durum, Bölgenin Kretase, Eosen ve Miyosen yaşlı kireçtaşları ile çevrili olması ve bu kayaçlarda çözünmeyen artık materyal olarak tanımlanan demirli bileşiklerin kırmızı topraklarda yaygın olması ile ilişkilendirilebilir (Durn, 2003). Ayrıca Kızıltepe'nin Sahra ve Suriye çöllerinden her yıl taşınan demirce zengin materyalin (Çöl tozu) etkisi altında kalması, toprakların demir içeriğinin yüksek olmasının diğer bir nedeni olabilir (Kubilay ve ark. 1997, Atalay ve ark. 2018).

Çalışma alanı topraklarının alınabilir mangan $(\mathrm{Mn})$ içeriği 2.79-6.71 $\mathrm{mg} \mathrm{kg}^{-1}$ olarak belirlenmiş olup, toprakların alınabilir Mn içerikleri Viets ve Lindsay (1973)'e göre "yeterli" düzeyde (>1 $\left.\mathrm{mg} \mathrm{kg}^{-1}\right)$ olduğu görülmüştür. Toprakların bakır $(\mathrm{Cu})$ içeriği, örneklerde $0.10-1.58 \mathrm{mg}$ $\mathrm{kg}^{-1}$ arasında değişim göstermiş olup, ortalama 1.58 $\mathrm{mgkg}^{-1}$ olarak belirlenmiştir. Linsay ve Norvell (1978)'in bildirdiği sınır değerlerine göre toprakların bütününün alınabilir $\mathrm{Cu}$ içeriği bakımından İnandı köyünden alınan iki örnekte "az" $\left(<0.2 \mathrm{mg} \mathrm{kg}^{-1}\right)$ olduğu ve geri kalan örneklerde "yeterli" düzeyde $\left(>0.2 \mathrm{mg} \mathrm{kg}^{-1}\right)$ olduğu belirlenmiştir.

Örnekleme yapılan tarım arazilerinde Nikel (Ni) konsantrasyonu 1.04-2.99 mg kg-1 arasında değiştiği, kadmiyum (Cd) konsantrasyonunun ise $0.25-3.89 \mathrm{mg} \mathrm{kg}$ 
${ }^{1}$ arasında değiştiği belirlenmiştir. Çevre ve Orman Genel Müdürlüğü tarafından pH'sı 6'dan büyük topraklar için izin verilebilir maksimum ağır metal konsantrasyonları, $\mathrm{Ni}$ için $75 \mathrm{mg} \mathrm{kg}^{-1}$ ve $\mathrm{Cd}$ için 0.02-4 $\mathrm{mg} \mathrm{kg}^{-1}$ dır (Bilge ve Çimrin, 2013). Gereğinden fazla fosforlu gübre kullanımında tarım topraklarında ağır metal birikimi meydana gediği bilinmektedir. Her ne kadar toprakların $\mathrm{Ni}$ ve $\mathrm{Cd}$ miktarları normal sınırlar içerisinde gözükse de $\mathrm{pH}^{\prime}$ sı 6 dan büyük topraklarda bu kadar yarayışlı Ni ve $\mathrm{Cd}$ bulunması fosforlu gübrelerin yapımında kullanılan ve ithal edilen ham fosfat kayası ve fosforik asitin $\mathrm{Ni}$ ve $\mathrm{Cd}$ içeriğinin yüksek olması ile ilgili olabilir.

Çizelge 2. Çalışma alanı toprakların bazı fiziksel ve kimyasal analiz sonuçları

Table 2. Some physical and chemical analysis results of the study area soils

\begin{tabular}{|c|c|c|c|c|c|c|c|c|c|c|c|c|c|}
\hline \multirow[b]{2}{*}{ Köy } & \multirow[b]{2}{*}{ Bünye } & \multirow[b]{2}{*}{ pH } & \multicolumn{3}{|c|}{$\%$} & $\mathbf{P}$ & $K$ & $\mathrm{Zn}$ & $\mathrm{Fe}$ & Mn & $\mathrm{Cu}$ & $\mathrm{Ni}$ & $\mathrm{Cd}$ \\
\hline & & & $\mathrm{CaCO}_{3}$ & Tuz & O.M. & \multicolumn{8}{|c|}{$\mathrm{mg} \mathrm{kg}^{-1}$} \\
\hline Aktepe-1 & $\mathrm{CL}$ & 7.58 & 22.0 & 0.036 & 2.32 & 16.8 & 1172 & 0.62 & 18.6 & 3.41 & 0.78 & 1.55 & 1.92 \\
\hline Aktepe-2 & $\mathrm{CL}$ & 7.33 & 25.5 & 0.031 & 1.87 & 17.1 & 1220 & 0.52 & 15.6 & 2.86 & 0.65 & 1.30 & 1.61 \\
\hline Aktepe-3 & $\mathrm{CL}$ & 7.25 & 26.2 & 0.055 & 1.84 & 16.2 & 1123 & 0.99 & 29.8 & 5.46 & 1.24 & 2.48 & 3.07 \\
\hline Altıntoprak-1 & $\mathrm{CL}$ & 7.48 & 22.9 & 0.068 & 1.55 & 14.1 & 987 & 1.26 & 37.8 & 6.93 & 1.58 & 3.15 & 3.89 \\
\hline Altıntoprak-2 & $\mathrm{CL}$ & 7.17 & 24.0 & 0.065 & 1.64 & 15.2 & 1125 & 1.19 & 35.8 & 6.57 & 1.49 & 2.99 & 3.69 \\
\hline Altıntoprak-3 & $\mathrm{CL}$ & 7.50 & 23.6 & 0.062 & 2.14 & 12.9 & 974 & 0.55 & 16.4 & 3.01 & 0.68 & 1.37 & 1.69 \\
\hline Çağıl-1 & $\mathrm{CL}$ & 7.34 & 31.8 & 0.036 & 2.14 & 14.9 & 684 & 0.62 & 18.6 & 3.41 & 0.77 & 1.55 & 1.91 \\
\hline Çağıl-2 & $\mathrm{CL}$ & 7.49 & 25.0 & 0.037 & 1.69 & 15.8 & 765 & 0.65 & 19.4 & 3.56 & 0.52 & 1.04 & 1.29 \\
\hline Çağıl-3 & $\mathrm{CL}$ & 7.35 & 25.7 & 0.041 & 1.81 & 13.7 & 730 & 0.73 & 21.8 & 3.99 & 0.91 & 1.81 & 2.24 \\
\hline Çamlıca-1 & $\mathrm{CL}$ & 7.45 & 27.0 & 0.038 & 1.73 & 24.9 & 780 & 0.65 & 19.6 & 3.60 & 0.82 & 1.63 & 2.02 \\
\hline Çamlıca-2 & $\mathrm{CL}$ & 7.51 & 24.1 & 0.040 & 2.37 & 22.4 & 762 & 0.70 & 21.1 & 3.87 & 0.88 & 1.76 & 2.17 \\
\hline Çamlıca-3 & $\mathrm{CL}$ & 7.49 & 23.9 & 0.036 & 2.06 & 21.2 & 720 & 0.63 & 18.8 & 3.44 & 0.78 & 1.56 & 1.93 \\
\hline Çamlıdere-1 & $\mathrm{CL}$ & 7.71 & 26.2 & 0.042 & 1.77 & 10.7 & 615 & 0.75 & 22.5 & 4.12 & 0.94 & 1.87 & 2.32 \\
\hline Çamlıdere-2 & $\mathrm{CL}$ & 7.40 & 31.3 & 0.061 & 1.83 & 9.8 & 597 & 1.11 & 33.3 & 6.11 & 1.39 & 2.78 & 3.43 \\
\hline Çamlıdere-3 & $\mathrm{CL}$ & 7.45 & 28.3 & 0.047 & 1.32 & 8.3 & 625 & 0.83 & 25.0 & 4.59 & 1.04 & 2.09 & 2.58 \\
\hline Ekinlik-1 & $\mathrm{CL}$ & 7.81 & 18.7 & 0.040 & 1.7 & 8.5 & 825 & 0.71 & 21.2 & 3.90 & 0.89 & 1.77 & 2.19 \\
\hline Ekinlik-2 & $\mathrm{CL}$ & 7.75 & 23.9 & 0.041 & 1.6 & 9.9 & 796 & 0.57 & 17.1 & 3.14 & 0.71 & 1.43 & 1.77 \\
\hline Ekinlik-3 & $\mathrm{CL}$ & 7.62 & 19.5 & 0.042 & 1.96 & 8.9 & 776 & 0.71 & 21.4 & 3.92 & 0.89 & 1.78 & 2.20 \\
\hline İnandı-1 & $\mathrm{CL}$ & 7.56 & 33.7 & 0.035 & 1.80 & 13.2 & 633 & 0.61 & 18.2 & 3.34 & 0.11 & 1.22 & 0.27 \\
\hline İnandı-2 & $\mathrm{CL}$ & 7.52 & 26.7 & 0.058 & 2.10 & 11.0 & 604 & 1.06 & 31.7 & 5.81 & 0.33 & 1.66 & 0.82 \\
\hline İnandı-3 & $\mathrm{CL}$ & 7.62 & 27.6 & 0.066 & 1.57 & 12.1 & 591 & 1.22 & 36.6 & 6.71 & 0.10 & 1.20 & 0.25 \\
\hline Sandıklı-1 & $\mathrm{CL}$ & 7.29 & 22.4 & 0.030 & 1.60 & 12.1 & 752 & 0.51 & 15.2 & 2.79 & 0.63 & 1.27 & 1.57 \\
\hline Sandıklı-2 & $\mathrm{CL}$ & 7.59 & 20.8 & 0.034 & 1.99 & 13.3 & 773 & 0.58 & 17.3 & 3.17 & 0.72 & 1.44 & 1.78 \\
\hline Sandıklı-3 & $\mathrm{CL}$ & 7.32 & 24.5 & 0.041 & 1.93 & 11.0 & 803 & 0.72 & 21.7 & 3.98 & 0.90 & 1.81 & 2.24 \\
\hline Tozan-1 & $\mathrm{CL}$ & 7.59 & 29.4 & 0.037 & 1.85 & 17.0 & 757 & 0.64 & 19.2 & 3.53 & 0.80 & 1.60 & 1.98 \\
\hline Tozan-2 & $\mathrm{CL}$ & 7.47 & 25.2 & 0.046 & 2.12 & 15.9 & 739 & 0.81 & 24.4 & 4.48 & 1.02 & 2.03 & 2.51 \\
\hline Tozan-3 & $\mathrm{CL}$ & 7.34 & 28.4 & 0.042 & 1.88 & 18.1 & 780 & 0.69 & 20.6 & 3.78 & 0.86 & 1.72 & 2.12 \\
\hline Yaşarköy-1 & $\mathrm{CL}$ & 7.38 & 29.9 & 0.035 & 1.72 & 10.9 & 693 & 0.60 & 18.1 & 3.31 & 0.75 & 1.51 & 1.86 \\
\hline Yaşarköy-2 & $\mathrm{CL}$ & 7.45 & 27.2 & 0.042 & 1.72 & 12.4 & 728 & 0.74 & 22.2 & 4.07 & 0.92 & 1.85 & 2.29 \\
\hline Yaşarköy-3 & $\mathrm{CL}$ & 7.36 & 28.9 & 0.036 & 1.54 & 11.6 & 701 & 0.62 & 18.6 & 3.41 & 0.77 & 1.55 & 1.91 \\
\hline En düşük & & 7.17 & 18.7 & 0.030 & 1.32 & 8.25 & 591 & 0.51 & 15.2 & 2.79 & 0.10 & 1.04 & 0.25 \\
\hline En yüksek & & 7.81 & 33.7 & 0.068 & 2.37 & 24.9 & 1120 & 1.26 & 37.8 & 6.71 & 1.58 & 2.99 & 3.89 \\
\hline Ortalama & & 7.47 & 25.8 & 0.044 & 1.84 & 14.0 & 794 & 0.75 & 22.6 & 4.14 & 0.83 & 1.76 & 2.05 \\
\hline
\end{tabular}

Buğday tanelerinde protein, N, P, K, Zn, Fe, Mn, Cu, Ni ve Cd içerikleri

Mardin ili Kızıltepe ilçesinin bazı köylerinden alınan makarnalık buğday örneklerinin \% protein, N, P, K, Zn, Fe, $\mathrm{Mn}, \mathrm{Cu}, \mathrm{Ni}$ ve $\mathrm{Cd}$ konsantrasyonları Çizelge 3.'de verilmiştir. Buğday örneklerinde protein içeriği \% 11 ile
\% 12.8 arasında değişim göstermiş olup, ortalama \% 11.8 protein içerdiği belirlenmiştir. Tanede protein miktarının çeşide bağlı olarak \% 9.2-16.8 arasında değiştiği (Atlı ve ark., 1990) ve protein oranının çevre şartları ve uygulanan kültürel işlemlere göre farklılık gösterdiği bilinmektedir (Öztürk ve ark., 2017). Buğday tanesi N 
içeriği \% 1.76 ile \% 2.02 arasında ortalama \%1.89 olarak belirlenmiştir. Kizilgöz ve Sakin (2009) buğday tanelerinde \% N içeriğinin 2.11-2.90 belirlemiştir. Bu çalışmada belirlenen en yüksek tane $N$ içeriğinin (\% 2.02) bile Kizilgöz ve Sakin (2009)' un alt sınırından bile düşük olması bitkilerde azotlu gübrelemenin gerektiğinin topraktaki organik madde noksanlığından sonraki ikinci kanıtıdır. Makro elementler bakımından buğday tanesi $\mathrm{P}$ içeriği \% 0.21 ile \% 0.47 arasında, $\mathrm{K}$ ise \% 2.22 ile \% 2.87 arasında değişim göstermiştir. Kizilgöz ve Sakin (2009) buğday tanelerinde \% N içeriğinin 2.11-2.90, \% P içeriğinin $0.25-3.00, \% \mathrm{~K}$ içeriğinin 0.69-2.00 arasında,
Tosun ve ark. (2019) ise \% $\mathrm{N}$ içeriğinin $1.49-2.54$ ve \% $\mathrm{P}$ içeriğini 0.24-0.40 arasında değiştiğini bildirmişlerdir.

Buğday tanelerinin Zn içeriği 13.3-17.2 $\mathrm{mg} \mathrm{kg}^{-1}$ arasında, ortalama $15.9 \mathrm{mg} \mathrm{kg}^{-1}$ olarak belirlenmiş olup, topraklara benzer şekilde tanede de $\mathrm{Zn}$ içeriklerin alt sınıra yakın olduğu görülmektedir. Bu durum topraktaki $\mathrm{Zn}$ noksanlığı yanında Fe fazlalığı ile ilgili olabilir. Öztürk (2018) ortalama buğday tanelerinde Zn miktarının 11.91$23.10 \mathrm{mg} \mathrm{kg}^{-1}$ arasında, Kizilgöz ve Sakin (2009) ise tane örneklerinin $\mathrm{Zn}$ içeriklerinin 14.0-37.1 mg kg-1 arasında değiştiğini belirtmiştir.

Çizelge 3. Buğday tanelerinde protein ve bazı element içerikleri

Table 3. Protein and some element contents in wheat grains

\begin{tabular}{|c|c|c|c|c|c|c|c|c|c|c|}
\hline \multirow{2}{*}{ Köyler } & Protein & $\mathbf{N}$ & $\mathbf{P}$ & $\mathrm{K}$ & $\mathrm{Zn}$ & $\mathrm{Fe}$ & $\mathrm{Mn}$ & $\mathrm{Cu}$ & $\mathrm{Ni}$ & Cd \\
\hline & \multicolumn{4}{|c|}{$\%$} & \multicolumn{6}{|c|}{$\mathrm{mg} \mathrm{kg}^{-1}$} \\
\hline Aktepe & 12.1 & 1.94 & 0.26 & 2.46 & 17.2 & 38.7 & 41.4 & 3.87 & 4.63 & 0.54 \\
\hline Altıntoprak & 11.5 & 1.84 & 0.32 & 2.63 & 16.3 & 35.1 & 37.5 & 3.51 & 6.98 & 0.53 \\
\hline Çağıl & 11.4 & 1.82 & 0.45 & 2.22 & 14.2 & 36.7 & 34.9 & 3.27 & 4.43 & 0.36 \\
\hline Çamlıca & 11.9 & 1.90 & 0.27 & 2.34 & 13.3 & 40.1 & 42.9 & 4.01 & 5.92 & 0.62 \\
\hline Çamlıdere & 11.1 & 1.78 & 0.38 & 2.23 & 15.2 & 33.9 & 36.2 & 3.39 & 6.67 & 0.59 \\
\hline Ekinlik & 12.6 & 2.02 & 0.42 & 2.57 & 16.2 & 41.3 & 44.2 & 4.13 & 5.16 & 0.48 \\
\hline İnandı & 11.5 & 1.84 & 0.21 & 2.87 & 17.2 & 35.0 & 37.4 & 3.50 & 5.90 & 0.14 \\
\hline Sandıklı & 12.5 & 2.00 & 0.34 & 2.75 & 15.5 & 40.0 & 42.8 & 4.00 & 5.65 & 0.42 \\
\hline Tozan & 12.3 & 1.97 & 0.47 & 2.8 & 18.5 & 40.5 & 43.3 & 4.05 & 4.49 & 0.40 \\
\hline Yaşarköy & 11.0 & 1.76 & 0.35 & 2.67 & 15.1 & 33.8 & 36.1 & 3.38 & 4.65 & 0.43 \\
\hline En Düşük & 11.0 & 1.76 & 0.21 & 2.22 & 13.3 & 33.8 & 34.9 & 3.27 & 4.43 & 0.14 \\
\hline EnYüksek & 12.6 & 2.02 & 0.47 & 2.87 & 17.2 & 41.3 & 43.3 & 4.13 & 6.98 & 0.62 \\
\hline Ort. & 11.8 & 1.89 & 0.35 & 2.55 & 15.9 & 37.5 & 39.7 & 3.71 & 5.45 & 0.45 \\
\hline
\end{tabular}

Ülkemizde $Z n$ 'nin yeterli olduğu topraklarda yetişen buğday tanesinde $\mathrm{Zn}$ içeriğinin genellikle $20-30 \mathrm{mg} \mathrm{kg}^{-1}$ arasında değiştiği, Zn eksikliği olan topraklarda $\mathrm{Zn}$ içeriğinin $5-12 \mathrm{mg} \mathrm{kg}^{-1}$ olduğu bildirilmiştir (Kalayci ve ark., 1999; Erdal ve ark., 2002). Dünya genelinde tahıl yetiştirilen alanların bir çoğunda, düşük toprak nemi, düşük organik madde ve yüksek $\mathrm{pH}$ gibi olumsuz fiziksel ve kimyasal faktörler nedeniyle bitki kökleri vasıtasıyla Zn alımında yetersizlikler görülebilmektedir (Çakmak, 2008; Barut ve ark., 2017).

Buğday tanelerinin Fe içeriği 33.8-41.3 mg kg ${ }^{-1}$ arasında ortalama $37.5 \mathrm{mg} \mathrm{kg}^{-1}$ olarak belirlenmiş olup, benzer şekilde Balint ve ark. (2001), buğdayın tanesinin Fe içeriğinin 22.3-48.9 mg kg ${ }^{-1}$ arasında, Suchowilska ve ark. (2012) 43-45 mg kg-1 arasında, Kizilgöz ve Sakin (2009) 12.4-53.7 $\mathrm{mg} \mathrm{kg}^{-1}$ arasında ve Tosun ve ark. (2019) ise 20 farklı buğday çeşidinde yapmış oldukları çalışmada tanenin $\mathrm{Fe}$ içeriğinin 21.9-45.5 mg kg-1 arasında değiştiğini bildirmişlerdir.
Buğday tanelerinin Mn içeriği 34.9-43.3 $\mathrm{mg} \mathrm{kg}^{-1}$ arasında, ortalama $39.7 \mathrm{mg} \mathrm{kg}^{-1}$ olarak belirlenmiş olup, Litoriya ve ark. (2018) tane $\mathrm{Mn}$ içeriğini 32.90-36.79 $\mathrm{mg} \mathrm{kg}^{-1}$, Tosun ve ark. (2019) ise 33.5-48.9 mg kg-1 arasında değiştiğini bildirmişlerdir. Buğday tanelerinde bakır (Cu) içeriği 3.27-4.13 mg kg-1 arasında, ortalama $3.71 \mathrm{mg} \mathrm{kg}^{-1}$ belirlenmiş olup, Kizilgöz ve Sakin (2009) tanedeki Cu içeriğini 2.30-5.70 mg kg-1, Öztürk (2018) farklı 6 çeşit buğday tanesinde $\mathrm{Cu}$ içeriğini 3.81-5.75 $\mathrm{mg} \mathrm{kg}^{-1}$, Tosun ve ark. (2019) ise Cu içeriğinin 3.64-6.98 $\mathrm{mg} \mathrm{kg}^{-1}$ arasında değiştiğini bildirmişlerdir.

Buğday taneleri Ni içerikleri bakımından ise 4.43-6.98 mg $\mathrm{kg}^{-1}$ arasında değişim göstermiştir. Günümüzde mutlak gerekli elementlerden biri olarak kabul edilen $\mathrm{Ni}$, tarım topraklarında çok azdır. Nikel yüksek bitkilerde, üreaz enziminin temel yapı maddesi olup enzimin aktivitesi için mutlak gereklidir (Klucas ve ark., 1983; Kacar ve Katkat, 2007). Buğday tanelerinde $\mathrm{Ni}$ içeriği $0.2-0.6 \mathrm{mg} \mathrm{kg}^{-1}$ arasında değişmektedir (Kabata-Pendias ve Pendias, 1992). Buğday taneleri Cd miktarı ise $0.14-0.62 \mathrm{mg} \mathrm{kg}^{-1}$ 
arasında değişim göstermiş olup, FAO/WHO verilerine bağlı olarak bitkilerde $\mathrm{Cd}$ üst sınır değeri $0.50 \mathrm{mg} \mathrm{kg}^{-1}$ olarak belirlenmiştir. Toprak örneklerinde bulunan $\mathrm{Ni}$ ve Cd element içeriklerinin kabul edilebilir seviyelerde olmasına rağmen yarayışı miktarlarının hafif yüksekliği, bazı buğday tanelerinde $\mathrm{Cd}$ ve $\mathrm{Ni}$ elementlerinin üst sınırda bulunması ile uyumlu olduğu öne sürülebilir.

\section{Toprak örneklerindeki bazı özellikler ile toprak ve tane özellikleri arasındaki ilişkiler}

Buğday ekimi yapılan alanlardan alınan toprak örneklerinin bazı fiziksel ve kimyasal özellikleri ile buğday tanesindeki özellikler aralarındaki ilişkiler Çizelge 4.'de verilmiştir. Çizelgenin incelenmesinden de anlaşılacağı gibi toprakların toplam tuz içerikleri ile alınabilir Zn, Fe, $\mathrm{Mn}$ aralarında çok önemli $(\mathrm{P}<0.01)$, Cd içerikleri arasında önemli $(P<0.05)$ pozitif ilişkiler belirlenmiştir. Ayrıca, toprakların organik madde içerikleri ile topraktaki yarayışı $P$ arasında da pozitif çok önemli $(P<0.01)$ ilişki belirlenmiştir. Karaduman ve Çimrin (2016) Gaziantep yöresi topraklarında, Çimrin ve Boysan (2006) Van yöresi topraklarında benzer olarak organik madde ile alınabilir $P$ arasında çok önemli ilişki belirlemişlerdir. Toprakların alınabilir $\mathrm{Zn}$ içeriği ile Fe ve $\mathrm{Mn}$ içerikleri arasında, alınabilir Fe ile $\mathrm{Mn}$ ve $\mathrm{Cu}$ arasında, alınabilir $\mathrm{Cu}$ ile Ni ve $\mathrm{Cd}$ arasında çok önemli $(\mathrm{P}<0.01)$ pozitif ilişkiler belirlenmiştir. Karaçal ve Çimrin (1997) Van yöresi topraklarında $\mathrm{Mn}-\mathrm{Zn}, \mathrm{Zn}-\mathrm{Cu}, \mathrm{Zn}-\mathrm{Fe}$ aralarında, önemli pozitif ilişkiler bildirmişlerdir. Çalışma alanı topraklarının kireç içeriği $\left(\mathrm{CaCO}_{3}\right)$ ile buğday tanesi, protein, $\mathrm{Fe}, \mathrm{Mn}$ ve $\mathrm{Cu}$ içerikleri arasında negatif önemli $(P<0.05)$ ilişkiler belirlenmiştir. $\mathrm{Bu}$ durum bize topraktaki aşırı kirecin bitkinin beslenmesinde bazı sorunlar çıkardığını göstermektedir. Topraktaki tuz, Zn, Fe ve Mn içerikleri ile buğday tanesindeki $\mathrm{Ni}$, toprak organik maddesi ile bitkideki Fe arasında pozitif önemli ilişki belirlenirken, topraktaki $\mathrm{Cu}$ ve $\mathrm{Cd}$ ile buğday tanesindeki $\mathrm{Cd}$ arasında pozitif önemli ilişkiler belirlenmiştir. Ayrıca, buğday tanesindeki $\mathrm{Zn}$ ile $\mathrm{K}$ arasında önemli $(P<0.05)$, yine tanedeki Fe ile $\mathrm{Mn}$ ve $\mathrm{Cu}$ arasında çok önemli $(\mathrm{P}<0.01)$ pozitif ilişkiler belirlenmiştir (Çizelge 4).

Çizelge 4. Toprak örneklerinin bazı özellikleri ile tanedeki besin elementleri arasındaki korelasyon katsayıları Table 4. Correlation coefficients between some properties of soil samples and nutrients in the grain

\begin{tabular}{|c|c|c|c|c|c|c|c|c|c|c|c|}
\hline & \multicolumn{8}{|c|}{ Toprak } & \multicolumn{3}{|c|}{ Tane } \\
\hline & $\mathrm{CaCO}_{3}$ & Tuz & O.M. & $\mathrm{Zn}$ & $\mathrm{Fe}$ & $\mathrm{Mn}$ & $\mathrm{Cu}$ & $\mathrm{Cd}$ & Protein & $K$ & $\mathrm{Fe}$ \\
\hline \multicolumn{12}{|l|}{ Toprak } \\
\hline $\bar{P}$ & -0.01 & -0.23 & $0.85^{* *}$ & & & & & & & & \\
\hline $\mathrm{Zn}$ & 0.29 & $0.96^{* *}$ & -0.35 & & & & & & & & \\
\hline $\mathrm{Fe}$ & 0.29 & $0.96^{* *}$ & -0.35 & $1.00^{* *}$ & & & & & & & \\
\hline $\mathrm{Mn}$ & 0.30 & $0.96^{* *}$ & -0.35 & $1.00^{* *}$ & $1.00^{* *}$ & & & & & & \\
\hline $\mathrm{Cu}$ & -0.31 & 0.27 & -0.16 & 0.10 & 0.10 & 0.10 & & & & & \\
\hline $\mathrm{Ni}$ & -0.12 & $0.69^{*}$ & -0.31 & 0.58 & 0.58 & 0.58 & $0.86^{* *}$ & & & & \\
\hline $\mathrm{Cd}$ & -0.22 & -0.13 & -0.10 & -0.23 & -0.23 & -0.23 & $0.88^{* *}$ & & & & \\
\hline \multicolumn{12}{|l|}{ Tane } \\
\hline$\overline{\% \text { protein }}$ & $-0.74^{*}$ & -0.36 & 0.55 & -0.46 & -0.46 & -0.46 & -0.07 & 0.02 & & & \\
\hline$P$ & -0.05 & -0.27 & -0.20 & -0.36 & -0.36 & -0.36 & 0.36 & 0.50 & 0.15 & & \\
\hline K & -0.03 & 0.16 & -0.06 & 0.12 & 0.13 & 0.13 & -0.41 & -0.54 & 0.31 & & \\
\hline $\mathrm{Zn}$ & 0.04 & 0.31 & 0.07 & 0.31 & 0.31 & 0.31 & -0.11 & -0.18 & 0.34 & $0.66^{*}$ & \\
\hline $\mathrm{Fe}$ & $-0.65^{*}$ & -0.52 & $0.68^{*}$ & -0.61 & -0.61 & -0.61 & -0.05 & 0.11 & $0.94^{* *}$ & 0.11 & \\
\hline $\mathrm{Mn}$ & $-0.66^{*}$ & -0.37 & 0.58 & -0.46 & -0.46 & -0.46 & 0.01 & 0.13 & $0.93^{* *}$ & 0.29 & $0.92^{* *}$ \\
\hline $\mathrm{Cu}$ & $-0.66^{*}$ & -0.37 & 0.58 & -0.46 & -0.46 & -0.46 & 0.01 & 0.13 & $0.93^{* *}$ & 0.29 & $0.92^{* *}$ \\
\hline $\mathrm{Ni}$ & -0.12 & $0.72^{*}$ & -0.34 & $0.71^{*}$ & $0.71^{*}$ & $0.71^{*}$ & 0.31 & 0.04 & 0.25 & -0.06 & -0.36 \\
\hline $\mathrm{Cd}$ & -0.40 & -0.05 & 0.11 & -0.16 & -0.17 & -0.17 & $0.83^{* *}$ & $0.86^{* *}$ & 0.06 & -0.59 & 0.18 \\
\hline
\end{tabular}

$*, * *$ sırasıyla $\mathrm{P}<0.05$ ve $\mathrm{P}<0.01$ düzeyinde istatistiksel olarak önemlidir.

Sonuç olarak, Mardin ili Kızıltepe ilçesinde belirlenen köylerde yer alan makarnalık buğday tarlalarının bazı kalite parametrelerinin belirlenmesi amacı ile 10 köyden üçer toprak ve 10 farklı makarnalık buğday tarlasından, alınan bitki örneklerinde gerekli analizler yapılarak sonuçları değerlendirilmiştir.
Toprakların organik madde içeriklerinin ve bitki $\mathrm{N}$ içeriklerinin düşük, $\mathrm{P}$ içeriklerinin yeterli düzeyde olduğu, $\mathrm{K}$ bakımından yeterli ve yüksek olduğu, $\mathrm{Zn}$ bakımında noksan olduğu, $\mathrm{Fe}, \mathrm{Mn}$ ve İnandı köyü örnekleri hariç $\mathrm{Cu}$ elementlerinin yeterli olduğu, $\mathrm{Ni}$ ve $\mathrm{Cd}$ konsantrasyonlarının ise kabul edilebilir sınırlar 
içerisinde olmasına rağmen $\mathrm{pH}^{\prime}$ sı 6 nın üzerindeki topraklar için hafif yüksek olduğu belirlenmiştir. Buğday örneklerinde protein içerikleri ortalama $\% 11.8$ proteine sahip olduğu, \% $P$ ve $K$ içeriğinin yeterli olduğu, $N$ ve $Z n$ elementlerinin yetersiz olduğu, Fe ve $\mathrm{Mn}$ bakımından yeterli olduğu belirlenmiştir.

Sonuç olarak, Mardin ili Kızıltepe ilçesi makarnalık buğday tarımı yapılan alanların beslenme sorunlarının olduğunu belirlenmiştir. Makarnalık buğday alanlarında yapılan bu çalışma sonuçları dikkate alınarak, uygun organik, azotlu ve çinkolu gübre doz çalışmalarının yapılarak, bu sonuçlara göre uygulanacak gübreleme programının belirlenerek çifçi eğitiminin yapılması gerekmektedir.

\section{ÖZET}

Amaç: Bu çalışmada Mardin ili, Kızıltepe ilçesi makarnalık buğday (Triticum durum Desf.) tarımı yapılan alanların verimlilik durumlarının toprak ve tane mineral analizleriyle belirlemesi amaçlanmıştır.

Yöntem ve Bulgular: Bu amaç için buğday tarımı yapılan alanlardan 10 ayrı noktadan ve her noktadan üç adet olmak üzere kök derinliği esasına göre 0-30 cm derinlikten toplam 30 adet arazi büyüklüğü ve topoğrafyası göz önünde bulundurularak toprak örnekleri ile buğday örnekleri alınmıştır. Alınan toprak örneklerinde, bünye, $\mathrm{pH}, \%$ kireç $\left(\mathrm{CaCO}_{3}\right)$, \% toplam tuz, organik madde (\% OM), bitkiye yarayışlı fosfor (P), potasyum $(\mathrm{K})$, çinko $(\mathrm{Zn})$, demir $(\mathrm{Fe})$, mangan $(\mathrm{Mn})$, bakır (Cu), nikel ( $\mathrm{Ni}$ ) ve kadmiyum (Cd) miktarları belirlenirken, buğday tanelerinde, \% Protein içeriği, azot $(N), P, K, Z n$, $\mathrm{Fe}, \mathrm{Mn}, \mathrm{Cu}, \mathrm{Ni}$ ve $\mathrm{Cd}$ konsantrasyonları belirlenmiştir.

Genel Yorum: Elde edilen bulgulara göre topraklar KilliTın bünyeli, nötr ve hafif alkalin reaksiyonlu, kireçli, tuzsuz ve genelde organik maddece fakir olduğu belirlenmiştir. Toprakların $\mathrm{P}$ içeriklerinin yeterli, $\mathrm{K}$ ve $\mathrm{Fe}$ içerikleri ise yeterli ve yüksek, $\mathrm{Mn}$ ve $\mathrm{Cu}$ içeriklerinin yeterli olarak belirlenirken, $\mathrm{Zn}$ içeriklerinin ise noksan olduğu belirlenmiştir. Buğday tane örneklerinde yapılan analizlerde protein oranı \% 11.00 ile 12.6 arasında ortalama \% 11.8 olarak bulunmuştur. Buğday tanesi örneklerinin $\mathrm{P}, \mathrm{K}, \mathrm{Mn}$ ve Fe içeriklerinin yeterli, $\mathrm{N}$ ve $\mathrm{Zn}$ içeriklerinin ise yetersiz olduğu belirlenmiştir.

Çalışmanın Önemi ve Etkisi: Sonuç olarak, Mardin ili Kızıltepe ilçesi makarnalık buğday tarımı yapılan alanların beslenme sorunlarının olduğu, özellikle bütün topraklarada organik madde, $\mathrm{N}, \mathrm{Zn}$ ve bazı topraklarda Cu noksanlığının bulunduğu ve yörede bilinçli bir bitki beslenme programlarının eksikliği belirlenmiştir.
Anahtar Kelimeler: Makarnalık (Triticum durum Desf.) buğday, toprak verimliliği, besin elementleri, ağır metaller, tane analizi.

\section{ÇIKAR ÇATIŞMA BEYANI}

Yazar(lar) çalışma konusunda çıkar çatışmasının olmadığını beyan eder.

\section{ARAŞTIRMACILARIN KATKI ORANI BEYANI}

Yazarlar çalışmaya eşit oranda katkı sağlamış olduklarını beyan eder.

\section{KAYNAKLAR}

Anonim (2019a) TUiK Bitkisel Üretim İstatistikleri. https://www.tuik.gov.tr/. (Erişim Tarihi: 10.10.2020)

Anonim (2019b) Mardin iline Ait İstatistiki Veriler. T.C. Tarım ve Orman Bakanlığı Meteoroloji Genel Müdürlüğü Kayıtları. https://www.mgm.gov.tr/ veridegerlendirme/il-ve-ilceler-istatistik.aspx? $\mathrm{k}=A \& \mathrm{~m}=$ MARDIN. (Erişim tarihi: 20.10.2019).

Atalay i, Saydam C, Kadir S, Eren M (2018) Pedogeomorphology. In: S Kapur, E Akça H Günal (eds) Soils of Turkey, 75-103, Springer. Chem.

Atlı A, Koçak N, Köksel H, Ercan R (1990) Türkiye'de yetiştirilen yerli ve yabancı buğday çeşitlerinin kaliteleri. Türkiye Ziraat Mühendisliği III. Teknik Kongresi, 8-12.

Ayçiçek M, Yürür N (1997) Türkiye tarımında makarnalık buğday üretimi ve önemi. Uludağ Üniversitesi Ziraat Fakültesi Dergisi 11: 267-275.

Ayyıldız AŞ, Eren A (2020) Evaluation of Productivity Status of Dry Farming Soils in Mardın Plain Using Geographical Information System Analyses. New Approaches and Applications in Agriculture. pp 252-264.

Bahçeci i, Ayde i (2008) Mardin-Kızıltepe Ovası yarı taşınabilir yağmurlama sulama sistemlerinin bazı performans parametrelerinin belirlenmesi. Harran Üniv. Zir. Fak. Derg. 12(1): 27-37.

Balint AF, Kovacs G, Erdei L, Sutka J (2001) Comparison of the $\mathrm{Cu}, \mathrm{Zn}, \mathrm{Fe}, \mathrm{Ca}$ and $\mathrm{Mg}$ contents of the grains of wild, ancient and cultivated wheat species. Cereal Research Communications 29(3-4): 375382.

Barut H, Aykanat S, Eker S, Çakmak i (2017) Ekmeklik buğdaya yapraktan farklı doz ve zamanlarda uygulanan çinko ve azotun tanenin besin elementi içeriğine etkisi. Çukurova Tarım ve Gıda Bilimleri Dergisi 32(2): 1-14. 
Bilge U, Çimrin KM (2013) Heavy metal pollution in soils adjacent to the Kızıltepe-Viranșehir road. Tarım Bilimleri Dergisi 19(4): 323-329.

Bozgeyik T, Çimrin KM (2020) Gaziantep ili Nizip ilçesi antepfıstığı ağaçlarının yaprak ve toprak örnekleri ile beslenme durumunun belirlenmesi. KSÜ Tarım ve Doğa Derg. 23(3): 722-732.

Bremner JM (1965) Methods of soilanalysispart 2. chemical and microbiologicalproperties. in ed. American Society of gronomy, Inc. Pub. Argon Series, No.9 Madison. Wisconsin, U.S.A.

BUGEM(2021)https://www.tarimorman.gov.tr/BUGEM/ Belgeler/M\%C4\%BOLL\%C4\%BO \%20 TARIM /\%C3\%9Cr\%C3\%BCn\%20Masalar\%C4\%B1\%2OHaz iran\%20Ay\%C4\%B1\%20B\%C3\%BClteni/Bu\%C4\%9 Fday\%20Haziran\%20B\%C3\%BClteni.pdf (Erişim Tarihi: 20.01.2021).

Cakmak I (2008) Enrichment of cereal grains with zinc: Agronomic or genetic biofortification? Plant Soil 302: 1-17.

Çığ F, Karaman M (2019) Güneydoğu Anadolu orijinli yerel makarnalık buğday (Triticum durum Desf.) genotiplerinin bazı tarımsal karakterler bakımından değerlendirilmesi. Türkiye Tarımsal Araştırmalar Dergisi 6(1): 10-19.

Çimrin KM (2018) Gaziantep ili kiraz (Prunus avium L.) bahçelerinin beslenme durumları. Adyutayam Dergisi 6(2): 8-17.

Çimrin KM, Boysan S (2006) Van yöresi tarım topraklarının besin elementi durumları ve bunların bazı toprak özellikleri ile ilişkileri. Y.Y. Üniv. Ziraat Fak. Tarım Bilimleri Dergisi 16(2): 105-111.

Demir MK (2018) Geleneksel tarhana üretiminde tam buğday unu kullanımı. Akademik Gıda 16(2): 148155.

Dönmez B, Coşkan A (2020) Geç dönem yaprak gübrelemesinin buğdayın besin elementi içeriğine ve bazı kalite özelliklerine etkisi. Ziraat Fakültesi Dergisi 16-29.

Durn G (2003) Terra rossa in the Mediterranean region: parent materials, composition and origin. Geologia Croatica 56(1): 83-100.

Düzgüneş O, Kesic T, Kavuncu O, Gürbüz F (1987) Araştırma ve deneme metodları (İstatistik Metodları-II). Ankara Üniversitesi Ziraat Fakültesi Yayınları, 1021(295): 10-13.

Erdal I, Yilmaz A, Taban S, Eker S, Cakmak I (2002) Phytic acid and phosphorus concentrations in seeds of wheat cultivars grown with and without zinc fertilization. J Plant Nutr. 25: 113-127.

Eren A (2019) Kızıltepe yöresinde buğday tarımı yapılan toprakların verimlilik durumlarının belirlenmesi. Gaziosmanpaşa Bilimsel Araştırma Dergisi 8(1): 1-9.

Eyüpoğlu F, Kurucu N, Talaz S (1998) Türkiye topraklarının bitkiye yarayışlı bazı mikro elementler (demir, bakır, çinko, mangan) bakımından genel durumu. T.C. Başbakanlık Köy Hizmetleri Genel Müdürlüğü, Toprak Gübre Araştırma Enstitüsü. Ankara. 1998.

FAO (1990) Micronutrient, assessment at the country level: An International Study. FAO Soil Bulletin by Mikko Sillanpaa. Rome.

Isaac RA, Johnson WC, Kalra Y (1998) Elemental determination by inductively coupled plasma atomic emission spectrometry. Handbook and reference methods for plant analysis. CRC Press, New York. pp 165-170.

Isaac RA, Kerber JD (1971) Atomic absorption and flame photometry: Techniques and uses in soil, plant, and water analysis. Instrumental Methods for Analysis of Soils and Plant Tissue 17-37.

Jackson M (1962) Soil Chemical Analysis. Prentice-Hall Inc., Englewood Cliffs, pp: 498, New Jersey, USA.

Kabata-Pendias A, Pendias $H$ (1984) Trace elements in soil and plants. $2^{\text {nd }}$ ed. P. 1-365. CRS press, London.

Kacar B, Katkat V (2007) Bitki Besleme. Nobel Yayın, 659 $\mathrm{s}$, Ankara.

Kalayci M, Torun B, Eker S, Aydin M, Ozturk L, Cakmak I (1999) Grain yield, zinc efficiency and zinc concentration of wheat cultivars grown in a zincdeficient calcareous soil in field and greenhouse. Field Crops Res. 63: 87-98.

Karaçal I, Çimrin KM (1997) Yüzüncü Yıl Üniversitesi kampüs alanı toprak profillerinin $\mathrm{Zn}$ durumu ve bu elementin bazı toprak özellikleri ile ilişkileri. ।. Ulusal Çinko Kongresi, 12-16 Mayıs, Eskişehir, 123130.

Karaduman A, Çimrin KM (2016) Gaziantep yöresi tarım topraklarının besin elementi durumları ve bunların bazı toprak özellikleri ile ilişkileri. KSÜ Doğa Bil. Derg. 19(2): 117-129.

Keleş-Uzel N, Çimrin KM (2020) Gaziantep ili Nizip ilçesi zeytin bahçelerinin yaprak ve toprak örnekleri ile beslenme durumunun belirlenmesi. KSÜ Tarım ve Doğa Derg. 23(4): 1039-1053.

Kellogg CE (1952) Our garden soils. Soil Science 74(2): 175.

Kendal E, Tekdal S, Aktaş H, Karaman M (2012) Bazı makarnalık buğday çeşitlerinin Diyarbakır ve Adıyaman sulu koşullarında verim ve kalite parametreleri yönünden karşılaştırılması.Uludağ Üniversitesi Ziraat Fakültesi Dergisi 26(2): 1-14. 
Kizilgöz I, Sakin E (2009) Suruç ovası sulu koşullarında yetiştirilen buğdayın makro ve mikro besin elementleri ile beslenme durumu. Harran Üni. Ziraat Fakültesi Derg. 353: 52-55.

Klucas RV, Hanus FJ, Russell SA, Evans HJ (1983) Nickel: a micronutrient element for hydrogen-dependent growth of Rhizobium japonicum and for expression of urease activity in soybean leaves. Proceedings of the National Academy of Sciences 80(8): 2253-2257.

Kubilay NN, Saydam AC, Yemenicioglu S, Kelling G, Kapur S, Karaman C, Akça E (1997) Seasonal chemical and mineralogical variability of atmospheric particles in the coastal region of the Northeast Mediterranean. Catena 28(3-4): 313-328.

Lindsay WL, Norwel WA (1978) Development of a DTPA test for zinc, iron, manganese and copper. J. Soil Sci. Am. 42: 421-428.

Litoriya NS, Modi AR, Talati JG (2018) Nutritional evaluation of durum wheat with respect to organic and chemical fertilizers. Agricultural research 7(2): 152-157.

Loeppert RH, Suarez DL (1996) Carbonate and Gypsum. In Methods of Soil Analysis. Part 3. Chemical

Olsen SR (1954) Estimation of available phosphorus in soils by extraction with sodium bicarbonate. United States Department of Agriculture; Washington.

Özberk F, Karagöz A, Özberk i, Atlı A (2016) Buğday genetik kaynaklarından yerel ve kültür çeşitlerine; Türkiye'de buğday ve ekmek. Tarla Bitkileri Merkez Araştırma Enstitüsü Dergisi 25(2): 218233.

Öztürk i, Kahraman T, AVCI R, Girgin VÇ, Çiftçigil TH, Tülek A, Tuna B (2017) Makarnalık buğday (Triticum Durum L.) genotiplerinin agronomik karakterler ve kalite parametreleri yönünden değerlendirilmesi. Bahri Dağdaş Bitkisel Araştırma Dergisi 6(2): 33-43.

Öztürk P (2018) Çeşitli organik bakliyat ve hububat ürünlerinde bazı makro ve mikro element içeriklerinin indüktif eşleşmiş plazma-optik emisyon spektroskopisi (ICP-OES) cihazı ile belirlenmesi. Yüksek Lisans Tezi, Namık Kemal Üniversitesi. Fen Bilimleri Ens., Gıda Mühendsiliği ABD. $101 \mathrm{~s}$.

Parlak M, Fidan A, Kızılcık I, Koparan H (2008) Eceabat ilçesi (Çanakkale) tarım topraklarının verimlilik durumlarının belirlenmesi. Ankara Üniversitesi Ziraat Fakültesi Tarım Bilimleri Dergisi 14(4): 394400.
Plank CO (1992) Plant analysis procedures for the southern region of the United States. Southern Cooperative Series Bulletin. pp 368.

Pratt PF (1965) Potassium. Ed. C. A. Black. Methods of Soil Analysis. Part 2. Am. Soc. Ag. Inc. Publisher, Madison, Wisconsin, U.S.A. pp 1022-1030.

Richards LA (1954) Diagnosis and improvement of saline and alkali soils. United States Department of Agriculture Handbook, 60.

Sillanpää M (1990) Micronutrient assessment at the country level: An international study. In : FAO Soils Bulletin N. 63.

Sönmez ME (2012) Kızıltepe ilçesinde bitkisel ürün deseninde meydana gelen değişimler ve olası olumsuz sonuçları. Coğrafi Bilimler Dergisi 10(1): 39-62.

Suchowilska E, Wiwart M, Kandler W, Krska R (2012) A comparison of macro-and microelement concentrations in the whole grain of four Triticum species. Plant, Soil and Environment 58(3): 141147.

Sumner ME, Miller WP (1996) Cation exchange capacity and exchange cations. pp. 1201-1229. In: Sparks, D.L. (Ed), methods of Soil Analysis. Part 3, Chemical Methods, ASA and SSSA, Madison, WI, SSSA Book Series No: 5.

Tosun YK, Erdem H, Tutus Y, Akbikk M, Ozkutlu F (2019) Relationship between plant sterols (b-sitositerol, campesterol, stigmasterol) and nutrients of bread wheat cultivars. Fresenius Environmental Bulletin 28: 1707-1714.

TÜIK(2021)https://arastirma.tarimorman.gov.tr/bzmai/l ink/2/istatistikler-tuik. (Erişim Tarihi: 10.01.2021).

Turan MA, Katkat AV, Özsoy G, Taban S (2010) Bursa ili alüviyal tarım topraklarının verimlilik durumları ve potansiyel beslenme sorunlarının belirlenmesi. Uludağ Üniversitesi Ziraat Fakültesi Dergisi 24(1): 115-130.

Ülgen N, Ateşalp M (1972) Toprakta bitki tarafından alınabilir fosfor tayini. Toprak Su Genel Müdürlüğü, Toprak ve Gübre Araştırma Enstitüsü, Teknik Yayınlar Serisi, Sayı 21, Ankara, 17 s.

Viets FG, Lindsay WL (1973) Testing soils for zinc, copper, managanese and iron. Soil Soc. of Amer. Inc. Madison Wisconcin. USA. pp 153-172. 